\title{
Albanian Parliament and Reforms in the Education Sector in 1928- 1933
}

\author{
Bashkim Boseta \\ Ph.D candidate. Faculty of History and Philology, University of Tirana, Albania. \\ Email: bashkimboseta@yahoo.it
}

Doi:10.5901/ajis.2014.v3n3p345

\begin{abstract}
Albanian Parliament during the years 1928-1933, where National education had a broad and complex treatment. In discussions of these years, were treated issues such as amendments to the legal framework of the education system, problems of scholarship funds, territories for foreign schools, the situation of migrant students etc.. Most important issues of these years, were the discussion and approval in February 1933 the Decree-Law on Prevention of Albanian students attending foreign schools and changed in April 1933 with the Articles 206, 207 of the Basic Statute of the Kingdom of Albania, which stipulates the closure of private schools in Albania.
\end{abstract}

\section{Legal Reforms before the Parliament in the Field of Education during 1928}

In April 1928, the Parliament discussed and approved the draft of the organic laws which were presented accurately to education -division, function, types of schools, duties of officers, teachers, students, parents, etc.. Among other things in this bill stipulated that primary education was in compulsory and free for men and women, parents who do not enroll a child in school age and who do not obey school committee councils sentenced to a fine fee condemns of 5 to 100 franga in gold money's . (Notices Speaches of the Parliament, 1928, pp. 199-200).

On 1 September 1928, Albania was proclaimed Kingdom. In several meetings of Parliament, were discussed and approved articles of the Basic Statute of the Kingdom. Among them were and articles 206, 207 who refered to national education. In art 206,formulated by the relevant parliamentary committee said that: "Primary education made only in secondary schools was free and compulsory. Secondary schools and university (higher education) only disclosed to the state. The contents of this article had a lot of discussions. Xhafer Ypi, the Minister of Education stated that he had been in commission when the item was formulated and expressed opposition, that the primary monopoly of state. He asked that this be given education in private schools of Albanian citizens. For this Mr.Ypi had prepared his formulation for art nr206, stating: "Primary education for all Albanian citizens was compulsory and free schools given by the state". This proposal was accepted. (Talks of Parliament,1928, p. 261). Art 207 was formulated thus: "In conformity with the laws and within the principles and programs of the State received for its schools and always under the effective control of the Government, only Albanian citizens can open different private schools. Foreigners in conformity of the law, can be allowed only for agro- technical schools, and the agricultural program theory, or practice. Can also be opened from the Albanian religious communities, also religious schools with the permission of the competent ministry in conformity with the law. The necessary number of religious schools of any community, and the number of students in these schools, would be determined by the competent Ministry with the Council of Ministers. (Talks of Parliament, 1928, p. 263). This article was accepted without changes.

During this period are discussed and approved several additions and changes to the categorization of teachers appointed a law. So in April 1928 was discussed and approved the law annexes of 12. VI. 1927 on the categorization of teachers. In Art 1 said that taking the exam the teacher gave the right to pass a higher category. Not taking the exam and tried to disabling the various reports from three different inspectors to cause the collapse of the category. In Art 2 determined that teachers who had graduated or finished the normal school of state, forced to undergo for pedagogical proficiency exam after two-year in one internship and if you lose it, you will remain available by subtracting from category III to II. (Talks of Parliament, Volume 2, 1928, p. 27). Also in January 1929 discussed another standard law to categorize all teachers. During the discussions, noted debates that dealt mainly with the way the government brought in Parliament for discussion the Project of Laws. Thus Dr.Simonidhi for MP .Government urged alongside the new project, and it should bring the old that had changed, when they could not go 55 deputies in the archives to find. But Hikmet Delvina, Minister of Justice stated that, "Members must go to the archives themselves, seek and read, that is to make himself be the Government adopted what work remains to be done to them?". (Talks of Parliament,1929 pp. 467-468).

This PL(Project Law) was discussed in March 1929 and was presented for a vote along with the changes made 
.Among others things professor was replaced with the word teacher ,who was determined and teacher salaries was based on seniority and exams taken, etc.. (Talks of Parliament, in 1929, Volume 2, pp.131-134).

Meanwhile, despite the good will to undertake reforms and improvements in the education sector, was not observed any major positive result, because in most cases these reforms were not accompanied by adequate financial support, which will enable their implementation. This happened with the law annexes to categorize all teachers. These short comings were not on the sidelines of the Albanian press time at these years. They were covered with realism and criticism, and even in local newspapers of the time were close to this. "We have repeated several times noted the newspaper "Besa ", in November 1931 - is to say once again how government does not make a categorization based on quality, culture, the old service,without exception to all state civil employers, than absences will not be fulfilled and typing up as secretary of any other employee, without any comprehensive school in the city and in rest would take a hefty -salary of the teacher in the village, wich will be in misery with his cruel salary, than the situation will deteriorate, but will never improve. "(Besa, 1931, p. 2).

\section{An important issue in the years 1928-33 was the Albanian education and ways of administration and payment of scholarships for Albanian students, inside and outside of Albania.}

Problems of this matter took an important place in Parliament. Thus, in March 1928 the Albanian Parliament approved a bill -brought by the Government for foreign scholarships for April, May and June of that year. In May 1928 they discussed the draft budget.

Budget was provided for a more internal scholarships available -161,000 gold fr; External Scholarship - 218,000 fr gold, and fine arts - 40,000 gold fr. About these items were held a series of discussions by MPs(member of Parliament). In them were deputies like was observed to lobbying for funding for fine arts, but had different opinions regarding students who would benefit scholarships. So en visions the deputy Ferid Vokopola stressed that "the Ministry of Education had done well will help to develop fine art, because the spirit was fostered not only by eating, are also needed for music and the arts". Talks of Parliament volume.2,1928,p.261). Xhafer Ypi, Minister of Education said, "If the fine arts have sent out girls and boys and if this fund enough then, they would be protected." (Talks of Parliament, Volume 2, 1928, p. 261). Sulejman Starova also supported investments for fine arts, but the main problem was with the students outside and scholarship payments for them. He stressed that, "wherever I go, Albanian students have found in cafes by making politics and some of them had not given exams someone else had entered into debt, they left without doing lessons and fled." (Talks of Parliament,Volume 2, 1928, p. 262).

Asked that he be supervised students in a way that will not go in vain all funding made. During discussions also were expressed other opinions. Said Toptani also urged Albanian students in Europe not only stood in capitals as demoralized, but also sent in small countries because so did to other states. (Parliament Talks 1928, Volume 2,p. 263) Over the years the issue of scholarships was noted a series of problems. This meant that in 1928 the Ministry of Education decided to react and benefit scholarship competition. However this measure is not brought any improvement after not implemented correctly.

Irregularities continued to grow especially in the provision of scholarships to persons not deserve, giving them out of competition, failure to return students to under the contract shall be returned after completion of studies, etc. Scholarships had a major impact on the budgets of poor Albanian Government and also giving them the wrong way they give opportunity for many talented students to pursue their studies. This lead to a reaction in public opinion and in various newspapers, which led to the intervention of the government. Began to take measures to regulate this issue as control of procedures for the granting of scholarships, and began their disruption. Interventions in this direction was taken by the Minister of Education Mr.Hil Mosi. In the first months of his arrival were cut 35 scholarships external and internal 100 scholarships that were given unjustly to children of wealthy families.

This initiative found its reflection and coverage in the media.Thus Mr. H. Mosi wrote in 1932 that the issue of termination of the scholarship will continue and those who had graduated were turned off and will not put on trial and would pay money spending back. The law was becoming hence the back, "not based either on poverty ,nor even in the favoritism in oldest tradition , but only in proficiency Fellowship. (Besa, 1932, p. 1)

Those action initiated by his Excellence Mr.Hil Mosi ended by the energetic Minister of Education Mr.Mirash Ivanaj which in October 1933, presented a draft to the Council of Ministers, which one was approved. In this project was determinate and calculate among other that will be awarded scholarships by type of school, the amount that will be given to students for scholarships, ways of payment and cut over 700 scholarships to students studying within or outside the state, which either were unworthy or not justified by the results. 


\section{Parliament and the financial problems of education}

Although the Albanian state had low income financial education funding issue was not on the sidelines of the Albanian Government. So in Parliament during 1928-33 were -discussed and approved additions and occasional transfers of funds in favor of the Ministry of Education. Despite this, there is achieved a great result after payments of teachers continued to be lower than the rest of the state administration. Also could see delays in payment of salaries to teachers.

In education funding and laws adopted in the bill presented for approval anticipated to contribute municipalities and residents of towns and villages. So in April 1928 was presented to the school buildings PL commotion. In art 1 determined that primary school buildings will rise to new or repaired at the expense of the population of cities or neighborhoods villages. XH.Ypi, Minister of Education said that the schools were in a very bad state, that does not deserve to be called by the name of the school, the buildings were even not for animals. He said, " These schools are not regulated, and will be destroyed (than no other project was presented in conformity with the law and enforce it first), before it even has been forced people to do these schools." (Talks of Parliament, Volume 2, 1928, p. 24).

Against this proposal ideas were some deputies. One of them deputy Rexhep Matja was declared against the acceptance of this law because according to him, "people were full loaded with heavy taxes." (Talks of Parliament, Volume 2, 1928, p. 24). However, after being brought to vote, the majority approved the Article nr.1, -where was written that residents would contribute to their costs, and will not appear in budgets of municipalities and communes. In primary state just pledged to pay the salary of teachers, and the establishment of the schools, should be provided by the municipal fund.

Debates were noted in early April 1928 on the proposal for the obtaining of a $2 \%$ tax from municipalities for the development of national education. Issues about these discussions was if municipalities should inclouse the tax burden, or should have to take it by the government found. Mr. F.Rusi appeal that "no sacrifice of $2 \%$ as the others had to make to the budget of municipalities". This sacrifice should be done because the state paid millions and to the municipalities were given the right to collect more taxes and it was not serious why would to pay $2 \%$ for national education. Milto Tutulani expressed his opposition of paying this tax by municipalities. He stated that this fund should be given by the government, which should help municipalities and used other sources. (Talks of Parliament, 1928, p. 184).

This debate continued in other meetings. In late April 1928 discussed the municipal tax abrogation of 2\% for national education and $1 \%$ for pensions. Report of the committee on education,finance, administration required the abrogation of only $2 \%$ for education and uphold the $1 \%$ for pensions. After much discussion it was decided to vote the bill abrogation from the government of that both taxes. (Talks of Parliament, Volume 2, 1928,p. 169).

In 1928 Albania after this were noticing an increase in foreign schools. Lands were taken by these schools in Albania like Greenfield, either as ground for professional staff practices and brought to occasional debates in Parliament. So in May 1928 several MPs(Member of Parliament) demanded explanations from the Minister of Finance on the issue of one land in Lapraka, who was awarded the American Technical school. They stated that it was state land that was given to U.S. and after school was out a somewhat thriving private equity and had taken documents. For this they sought clarification of the Minister of Finance .M.Tutulani, member of the Government, wich stated that he was unaware of it, but demanded to be put on the agenda, to study and after this will be able to give answers. ( Talks of Parliament, Volume 2, 1928, p. 273).

In early March 1931 was time to discuss the draft contract signed between the Ministry of Education of the Federation Est Near New-York on the building of the Albanian-American Institute. This institute will land up in Kavaja. This Institute would be for 100 boys and 100 girls who will be to specialize in agriculture. Students will be scholarships that will be paid by the Government and by the Institute. It is worth noting that Albania had received supportive measures regarding the establishment of this Institute. Thus, the Article 8 of the draft contract, stipulates that "all things that should be founding the Institute of buildings for education, exercise and vessels were excluded from every school and municipal duty in the present and in the future." ( Talks of Parliament, 1930-1931, p.245). After reading the draft contract of this in Parliament, discussions were noted. So Member of Parlament Mr Izedin Beshiri MP demanded to know, if that these lands that, were given to the Institute, were private, or municipal and if was state property or were private or were dispossessed? His Excellence H.Mosi Minister of Education in his reply stated that some lands were private, but are to be expropriated after a year. R.Mati expressed that they were happy to be upheld school, but the dismemberment of the people of the village, can not allow, because the statute prohibited. He said that in this regard "before a year had been taken in 1300 dynym (thousand meter2) and were not paid or pauper money and some did not even where driving a yoke of oxen."(Parliamentary Talks, 1930-1931, pp. 246 - 247).

Discussion on American school lands in Kavaja continued for some other sessions in Parliament on March 11 .. So in 1931, more deputies like R.Mati, S.Toptani, S.Stavri, presented an official document from the office where indicated 
in Kavaja mortgage that 200 acres of land that had been taken from the American school in Kavaja were communal property and wanted to see it coming and talking on the agenda. S.Toptani said, "it was not right that you were involved in village and school lands may find a different place." (Parliamentary Talks, 1930-1931, p. 317). What came after was to have prayer meeting focused on the population of the villages of Municipality of Kavaja on pastures that were expropriated in favor of theAmerican school. Mr Mihal Kaso attracted Parliament observed on two points: 1) Property was expropriated from villages without giving the rights duty.2) the Director of American school had put up in the municipality meadows and pastures unfairly. He asked that on these two points to discuss and to decide only the Parliament.(Parliamentary Talks, 1930-1931, p. 323) MPs (members of Parliament)were divided into two positions regarding this issue. One party was against giving land without first Institute indemnity, while the other party was in favor of granting land and later became reward. Mr Abdurrahman Dibra says that according to the new regulation, "the commission must submit a report should show all the actions that he had made inquiries on this issue or at the end of each month to submit a report Presidency together with a list of prayers and demands. So it was decided that the request of residents will be returning again to the committee for parliamentary discussion. (Parliamentary Talks, 1930-1931, p.323)

\section{Parliament and the Decree-Law of 14 September 1932 on theprohibition of Albanian students in foreign schools}

In the early 1930s we have a cooling time in the Italian-Albanian relations. "Signs of worsening relations seem that in October 1930, when the King Ahmet Zogu warned in 1930 that there was no intention of repeating the Pact of ItalianAlbanian 'friendship' (1926), whose terms ended in This year ". (History of Albanian People, Volume III,2007, p. 309). The goal was secession from Italian influence and attempted a rapprochement with the Balkan countries. For coping with the situation created by Italy, King needed public support. To achieve this, should be closer to their concerns. One of the biggest concerns for the public and constituted Patriots teachers, increased foreign schools and increase the number of Albanians who attended these schools.

Foreign schools had different functions. There were minority schools, professional, religious and school for children of foreign citizens. So Italian primary schools 'de jure' were set up for children of nationals Italy to Albania, but their aim was to include as many Albanian children. (Gogaj, Italian Educational Influence and Resitances v. Influence and Resistance and it's Albania.), 1980, p. 33 ). Albanian students in these schools were often under the influence of an ideology that feeling violated national and state secularism. With the advent of education in terms of $\mathrm{H}$. Mosi situation began to change. He was a partisan of secularism and patriotic-education. So with the July 24, 1930 along with Mr. Alexander Xhuvani the Government to submitted a report which among other things required the review of scholarship, substitute incompetent teachers, increase the budget for teachers, the nationalization of the Greek minority schools and gradually National Italian and American schools. In support of this position in August 1932 he presented to the King with a prefix urged the nationalization of schools. (History of Education and Pedagogy Albanian Thoughts, 2003, p. 437) Nationalization, went along with the intention of laicity of state schools. So the problem still remains the question of teaching religious subjects in state schools. For this was the feed-back from the patriotic teachers. These reactions were reported in the Albanian press- organs. So in the newspaper - 'Democrat' in April1930 - in an article of its historical evolution as talk of religious schools, made a call to the Minister of Education, among others was required, "harmful anachronism religious learning in state schools expects exterminate deadline from you. The precious veterans that you will find with a very large moral reward, cut and support your hand all those thorns that have remained in the beautiful garden and single national entity, which is the primary school. "Mr Hil Mosi you are lucky! "(Demokratia, 1930, pp. 3-4). An important role in terms of nationalism and secularism played and also one education magazine "New Education". This magazine had on its staff patriots and professional teachers. In December 1931 an article in this magazine among others stated that, "We hope that the parliament's, has left the hatch for an intervention of the state to religious authority in the right education, the right of the state entirely. Cannot be tolerated in any way, that the formation of conscience, a free citizen left in the hands of irresponsible. Religious authority should understand that religion and state are completely separate things. "(New Education, 1931, p. 339). With the constant interventions and teacher measures of the Ministry of Education in the year "1931 was reached that the teaching of religion was off school premises or at least outside official school hours." (Gogaj,I Reactionary attitude of the clergy in education, 1972, p. 128).

In the south of Albania's Greek minority schools existed. These schools for many years were out of focus and control of the Ministry had exceeded their powers. In these schools condoned disrespect, the programs of the Ministry of Education, etc. not using the Albanian language. In 1932 Jani Minga Inspector of Education, after a series of raids carried out, had concluded that "minority schools were turned into barracks with active soldiers, uniformed Greek ideology, 
subject to their apostolic task force. Therefore he sought the closure of these schools and putting them under the direction of the Albanian state. "(History of Education and Pedagogy Albanian Thought, 2003, p. 433).

The Albanian government under the Fundamental statute had the right to issue decree-laws, on important issues even when the parliamentary session had ended. Then the DL (Decree-Law) was discussed in Parliament when he gathered. On September 14, 1932 came the Decree-Law which prohibited the Albanian students to attend primary and secondary schools abroad. At this time Parliament was closed. This document does not require the closure of these schools but only by Albanian students to attend these schools.

Decree-Law is presented for discussion in Parliament in early February 1933. Among other things in this DL approved by the government stating that: Father and in the absence of the mother,grandfather or grandmother or guardian Albanian nationals whosend their children to foreign schools within or outside the U.S. primary persecuted by two to six months imprisonment and a fine amount of 500 to $1000 \mathrm{fr}$.of gold. Albanian students who had completed their studies in national schools under the same conditions were right,the candidacies of roughly preference for government employers on those who had completed their studies in Balkans schools states. Albanian students who attending classes in Occidental foreign schools and returning to Albania without exhausting experience were not accepted in government employers candidacy (without supplement their lessons in state schools). Albanian students who had reached adulthood and attended classes in a foreign schools with scholarships to foreign countries without the permission of the Ministry of Education were persecuted: a) with imprisonment of up to two months, b) with the exception of each respective officers to government three years from the date of receipt of the diploma.(Parliamentary Talks, from 1932 to 1933, p. 58).

In the report submitted by the Government justifying the Parliament, said that the situation of conducting the studies by Albanian students abroad had become quite problematic, and this situation had forced the Ministry of Education to take preventive measures and to occasionally have been taken three previous decisions by the Council of Ministers No. 192 dated 8th -1927 VIII, No. 848dated 13-XI-1928, No. 387 dated. 9-V-1929, but these decisions had not provided any certain effect. Then this ministry was necessary to develop a special $\mathrm{DL}$ (decret -law). With the application of this decree-laws was believed that this ministry would be closed once the best way to study all boys in primary schools and secondary thus ensuring a sound moral education of the next generation of patriotic. (Parliamentary Talks, from 1932 to 1933, p. 59).

Most of the deputies was agreed to approve the DL of Government. The only member who did not join the majority was Thoma Orolloga who said he was against the conviction of those who study foreign scholarships and would like those who had finished ahead of them Albanian schools with foreign schools. He stressed that the DL was premature, because our schools have not reached that stage as to compete with foreign schools. Education Minister Mr Mirash Ivanaj was against him and replied that, "the state's interest is to educate the younger generation and foreign schools can't totally educated even with our interests. Government has the right to take action because if Albanian students take a foreign politely, could the state tomorrow that these will entrust to guard the border? "(Parliamentary Talks,1932-1933, pp. 60-61). He stated that our schools draw students who had continued universities abroad.

During discussions of the Government Parliamentary Committee DL suffered some changes. Thus paragraph of Article III (1) was amended unanimously this: Excluded parents and guardians of children who for any reason a family living abroad. Article 3 was removed. Section 4 of Article 3 placed and changed in this way: Albanian students who have reached age 18 and who attend class in foreign schools with scholarships to foreign countries without the permission of the Ministry of Education punished, a) with imprisonment up to two months, b) with the exception of any government official to three years from the date of their graduation. For students who have not attained the age of 18 in terms of criminal liability, the penalties is in paragraphs. Thumbnail applied to parents or guardians or their tutor as following order as shown in Section 1. Commission had decided to proceed with an additional article this transistor DL with number4 that sanctioned: students who are found before the entry into force of this law, with scholarships to foreign countries, forcing them, or their parents or guardians or carers within three months from the date of publication of this law, only to make an announcement Ministry of Education on the state of their stock. If they would not have notice of the deadline, they will be punished as after section three of this law. (Parliamentary Talks, from 1932 - 1933, p. 102). On 20 February 1933 the DL and was eventually passed into law. Shortly in Summary we can say that the reforms undertaken in the education system over the years 1928-1933 brought:

First: improvements in terms of primary education, teachers and categorization problem scholarship. During these years were observed opposing views if primary education, which should be exclusive of the state, or should be private and, on the way of giving foreign school territories and funds for financing education.

Second: King policy, the reforms work and dedication of patriots- teachers , prepared the way for secularism and nationalism Albanian education.

Third: Decree-Law of 14 September 1932 marked a major step towards about the nationalization of education and 
set the stage for major reform in the Albanian education, devised and directed by Mirash Ivanaj, reform which will be addressed in one other work.

\section{References}

Besa. ( 3 november 1931) p. 2.

Besa ( 21 july 1932) p. 2.

"Demokratia" (12 april 1930) p.p 3-4

(New) Education "Schools and vice-attitudes". (1931, December) p. 339.

Talks of Parliament. (1928). Tirana.

Talks of Parliament (Vol. 2). (1928). Tirana.

Talks of Parliament . (1929). Tirana.

Talks of Parliament (Vol. 2). (1929). Tirana.

Talks of Parliament . (1930-1931). Tirana.

Talks of Parliament . (1932-1933). Tirana.

Gogaj, I. (1972).To reactionary instance on clergy education. Tirana:Mihal Duri.

Gogaj, I. (1980). Italian Influence in Education and Albanian Resistance. Tirana: "8 November Edition".

History of Education and Albanian Pedagogy (Vol. I).(2003). Tirana. "Mother Teresa".

History of Albanian People (Vol. III). (2007).Tirana: Toena. 